January 2011 China-paper-8.doc

\title{
HAS CHINA DE-INDUSTRIALISED OTHER DEVELOPING COUNTRIES?
}

\author{
Adrian Wood and Jörg Mayer \\ University of Oxford \\ United Nations Conference \\ on Trade and Development \\ adrian.wood@qeh.ox.ac.uk \\ joerg.mayer@unctad.org
}

\begin{abstract}
China's opening to trade is interpreted as a shift in world average factor endowments, which altered the comparative advantage of other countries. In the rest of the world on average, this shift lowered the share of labour-intensive manufacturing in the sum of labour-intensive manufacturing and primary output by 1 to 3.5 percentage points, and the corresponding export share by 1.5 to 5 points. The de-industrialising effect varied among countries, and was clearest in East Asia. It was significant, but not big enough to be a serious threat to growth or equity in most other developing countries.
\end{abstract}

\section{Acknowledgements}

Mauro Caselli provided extensive and excellent research assistance in the compilation and analysis of the data. Alicia Rapin also helped with the data. Valuable advice was received from referees. Useful comments were provided by seminar and conference audiences at Oxford, Sussex, Nottingham, Manchester, Geneva and WIDER. The opinions expressed are solely those of the authors and do not necessarily reflect the views of the institutions to which they are affiliated. 


\section{Introduction}

The least disputable of China's impacts on the world has been the explosion of studies of China's impact on the world. These range from broad analyses of global payments imbalances and interest rates (e.g. Dooley et al., 2004) to detailed examination of the exports of particular commodities by particular countries (e.g. Gallagher et al., 2008). Most of them refer to the past, but some forecast the future (e.g. Yang, 2003; Mayer and Fajarnes, 2008). They have used various methods, including inspection of trade data (e.g. Lall et al. 2005; Mesquita Moreira, 2007; Kaplinsky and Morris, 2008), revealed comparative advantage calculations (Lederman et al., 2008), gravity models (e.g. Greenaway et al., 2008; Hanson and Robertson, 2010) and computable general equilibrium (CGE) models (e.g. Dimaranan et al., 2006). To survey this literature would require an entire paper, but good bibliographies are available in Goldstein et al (2006), Winters and Yusuf (2006) and Broadman (2007).

The focus of the present paper is on how the entry of China into world markets over the past three decades has affected the broad sectoral structures of other economies, especially developing ones. It looks in particular at the balance between the two broad traded sectors that matter most to developing countries, namely labour-intensive manufacturing, which is often said to have been harmed by competition from China, and primary production, which is often said to have gained from increased demand by China. The effects of China on both these sectors in other developing countries have aroused concerns and suspicions about retarded industrialisation, reduced employment and increased inequality in Africa, Latin America and the rest of Asia.

The analysis in this paper goes beyond most other studies of the impact of China by examining the sectoral structure not only of exports but also of output (in this respect being similar to the CGE studies). It is also set in a more clearly specified theoretical framework - that of Heckscher and Ohlin (henceforth HO) - than most other studies. The relevance of HO is contested by Rodrik (2006), who finds China's exports to be more sophisticated than normal for its level of development, but his results are challenged by Xu (2007), Amiti and Freund (2008) and Schott (2008).

Section 2 explains how, in HO theory, the entry of China into world markets should affect the sectoral structures of other countries and outlines our method of estimating the size of this effect. Section 3 describes our data. Section 4 presents our calculations of the impact of China on world average endowments. Section 5 estimates the effects of endowments on output and export structures. Section 6 combines the results of the two previous sections into predictions of the impact of China on output and export structures in other countries. Section 7 compares the predictions with actual changes in these structures in developing countries. Section 8 concludes.

\section{Theory and method}

The impact of China on other countries can be interpreted in HO theory as occurring through a shift in world average factor endowments. The comparative advantage of a country depends on its endowments not in isolation but relative to the endowments of all other countries involved in trade. This comparator group was altered by China's emergence from near-autarky, because of its size and distinctive endowment structure, and hence so was the comparative advantage of other countries. 
More specifically, as will be documented later, China's opening to trade effectively lowered the world average land/labour ratio and increased the share of workers with a basic education in the world labour force. The relative endowments of other countries were thus shifted in the opposite directions, which tended to move their comparative advantage away from labour-intensive manufacturing, which requires a lot of workers with a basic education but not much land. The corresponding increase in comparative advantage for developing countries was mainly in primary production, which uses a lot of land; for developed countries, it was mainly in skill-intensive manufacturing and services, which need workers with more than a basic education.

The mechanism by which this shift in world average endowments took effect was a vast expansion of China's exports, concentrated on labour-intensive manufactures, in which its own endowments give it a comparative advantage, and of its imports, which are concentrated on primary products and skill-intensive manufactures, in which it has a comparative disadvantage. These changes in trade flows altered relative prices on world markets and shifted the demand functions faced by producers in other countries - inwards for labour-intensive manufactures, and outwards for primary commodities and skill-intensive manufactures. ${ }^{1}$

How large were these effects of China's opening on the sectoral structures of trade and output in other countries? A standard method of answering this question would be through simulations with a global CGE model, an approach that is in many ways attractive but would yield answers that were conditional on a lot of assumptions about functional forms and parameter values. We use a simpler method that involves more estimation and fewer assumptions, though it yields less precise answers.

More specifically, we estimate the impact on the output structure of country $z$ of a change in the composition of world endowments caused by the entry of China as

$$
\Delta q^{z} \approx-\left(\frac{\Delta q^{z}}{\Delta v^{z}}\right) \Delta v^{*}
$$

where $\Delta$ denotes the proportional change in a ratio, $q^{z}\left(=q_{M}^{z} / q_{P}^{z}\right)$ is country $z^{\prime}$ 's ratio of labour-intensive manufactured $(M)$ to primary $(P)$ output, and $v^{z}\left(=v_{B}^{z} / v_{N}^{z}\right)$ is country $z$ 's ratio of basic-educated workers $(B)$ to land $(N){ }^{2}$ The final term $\Delta v^{*}$ is the proportional change in the $B / N$ endowment ratio for the world as a whole (denoted by a $*$ superscript). The first, bracketed term on the right-hand side measures the effect on country z's output structure of a change in its own endowment ratio.

Our method is to estimate separately the two terms on the right-hand side of equation (1), and get our answer (the term on the left-hand side) by multiplying them together. The key assumption of this method, as can be seen by rearranging (1), is that

\footnotetext{
${ }^{1}$ The impact of China on primary commodity prices has been widely documented (e.g. Mayer and Fajarnes, 2008). Fu et al. (2010) show that China's exports depressed global manufactures prices.

${ }^{2}$ For simplicity, the exposition here assumes that there are only two factors, though three factors are used in our empirical analysis.
} 
$\frac{\Delta q^{z}}{\Delta v^{*}} \approx-\frac{\Delta q^{z}}{\Delta v^{z}}$

or, in words, that the effect on country $z$ 's output structure of a change in world average endowments is of roughly the same size as (though of opposite sign to) that of a change in its own endowments. At first sight, this approximate equality seems unlikely: in the usual (Heckscher-Ohlin-Samuelson) sort of HO model, the right-hand side of equation (2) is a Rybczynski relationship, whose size depends on the relative use of the two factors by the two goods in country $z$ at prevailing world prices, whereas the left-hand side is a non-standard composite,

$$
\frac{\Delta q^{z}}{\Delta v^{*}} \equiv \frac{\Delta q^{z}}{\Delta p^{*}} \frac{\Delta p^{*}}{\Delta v^{*}}
$$

of the effect of changes in world endowments on relative world prices, $p^{*}$, and the effect of changes in world prices on the output structure of country $z$.

To explain why the two ratios in equation (2) may be similar in size, despite the apparent differences between them, it is convenient to begin by expanding both of them, without their superscripts, into a common accounting identity

$$
\frac{\Delta q}{\Delta v} \equiv \frac{\Delta q}{\Delta p} \frac{\Delta p}{\Delta w} \frac{\Delta w}{\Delta v}
$$

which exposes three basic $\mathrm{HO}$ causal links: changes in relative factor endowments cause changes in relative factor prices (the final term, in which $w$ denotes the price of $B$ relative to $N$ ); changes in relative factor prices cause changes in relative goods prices by changing relative costs of production (the middle term); and changes in relative goods prices affect the composition of demand and hence of sales and output (the first term).

Both for an individual country and for the world, the three ratios on the right-hand side of the accounting identity in (4) can be interpreted as behavioural elasticities (a fuller theoretical treatment is in Wood, 2009):

$$
\begin{aligned}
& \frac{\Delta q^{z}}{\Delta y^{z}}=\varepsilon^{z} b_{M P}^{\prime} \omega^{\prime 2} \\
& \frac{\Delta q^{z}}{\Delta y^{*}}=c^{*} b_{M P}^{*} k^{*}
\end{aligned}
$$

The parameter $\varphi_{B N}$ is the elasticity of the relative price of factors $B$ and $N$ with respect to relative endowments of $B$ and $N$. In the usual sort of HO theoretical model, this elasticity would be zero for an individual open country: relative factor prices would be determined by world goods prices and unaffected by changes in relative endowments. In reality, the relative factor prices of countries that trade vary with their endowments, mainly because trade costs prevent relative goods prices being equalised (Davis and Weinstein, 2001; Romalis, 2004). However, the elasticity for an individual country, 


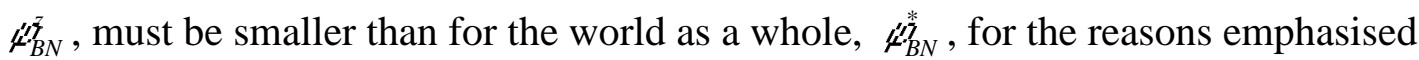
by $\mathrm{HO}$ theory: the world is a closed economy, but an individual country can adjust to changes in its endowments by altering exports and imports as well as by factor-priceinduced substitution among factors in production and domestic consumption.

The parameter $\theta_{M P}$ is the elasticity of relative goods prices with respect to relative factor prices. Its sign and size depend on the differences between the shares of the factors in the costs of producing the goods. For small changes in factor prices, it can be written more explicitly as $\left(\theta_{B M}-\theta_{B P}\right)$, whose two terms are the shares of $B$ in the costs of $M$ and $P{ }^{3}$ Since $M$ is more education-intensive than $P$, a fall in the relative price of basic-educated workers lowers the relative price of labour-intensive manufactures, to a degree depending on the size of the difference in education intensity. Unless technology is Cobb-Douglas, $\theta_{M P}$ varies among countries with their relative factor prices, but for an average country $\theta_{M P}^{z} \approx \theta_{M P}^{*}$.

The parameter $\varepsilon_{z}^{z}$ is a demand-side elasticity which determines how the relative sales of goods $M$ and $P$ by country $z$ vary with respect to the relative price of country $z$ 's varieties of these goods. It depends on the elasticities of substitution in consumption among different national varieties of each good, averaged across the two goods. In the usual sort of HO theoretical model, in which national varieties are perfect substitutes, $\varepsilon_{z}^{z}$ would be infinite. In practice, substitutability is imperfect (as is recognised in the Armington functions of CGE models and in the specification of gravity models), and $\varepsilon_{z}^{z}$ is further reduced by non-proportional - or 'per unit' - trade costs (Hummels and Skiba, 2004; Wood, 2009). A country's relative sales are thus usually affected in a systematic way by its own relative prices.

The parameter $\varepsilon_{z}^{*}$ determines how the relative sales of goods $M$ and $P$ by country $z$ vary with respect to the relative world prices of these goods (i.e. the average prices of all other national varieties). ${ }^{4}$ The effect of a change in relative world prices on country $z$ 's relative sales is evidently in the opposite direction to that of a change in its own relative prices. The effect is smaller, too: for example, a fall in $p_{M}^{*}$ would lower country $z$ 's share of the market for good $M$ to much the same extent as a rise in $p_{M}^{z}$ (depending on the elasticity of substitution between country $z$ 's and foreign varieties of good $M$ ); but a fall in $p_{M}^{*}$ would also and offsettingly expand the market for $M$ relative to $P$, to a degree determined by the elasticity of substitution between the two goods. The (absolute) size of $\varepsilon_{z}^{z}$ is thus likely to exceed that of $\varepsilon_{z}^{*}$.

This analysis of the constituent elasticities of equations (5a) and (5b) is the basis for the key assumption in equation (2). The difference of signs in (2) is due to the opposite signs of $\varepsilon_{z}^{z}$ and $\varepsilon_{z}$. The approximate equality of the sizes of the left-hand and right-hand sides of (2) is a result of $\theta_{M P}$ being similar, $\varepsilon_{z}$ being larger and $\varphi_{B N}$

\footnotetext{
${ }^{3}$ As for example in Wood (2009), taking $P$ to be the numeraire good and $N$ to be the numeraire factor.

${ }^{4}$ In the standard HO-Samuelson theoretical model, $\mathscr{E}_{z}$ exists only as an indirect relationship. Changes in factor prices caused by changes in world goods prices induce changes in the mix of factors used in each sector. The sectoral mix of output then needs to alter to allow factor markets to clear. In practice, however, a country's sales are likely to be affected directly by the prices of its competitors.
} 
being smaller for an average country than for the world as a whole. The difference in $\varepsilon_{z}$ between an average country and the world is assumed roughly to offset the opposite difference in $\varphi_{B N}$, since there is no reason to believe that one of these differences is proportionally larger than the other, but to the extent that this assumption is incorrect, so will be our results. ${ }^{5}$ More specifically, if the difference in $\varepsilon_{z}$ is larger than that in $\varphi_{B N}$, our method will overstate the impact of China on other countries, since the ratio on the right-hand side of (2) will be too large, and vice versa.

Variation in the sizes of $\varepsilon_{z}^{z}, \theta_{M P}^{z}$ and $k_{B N}^{z}$ among individual countries is not important for our method, which relies on an estimate of $\Delta q^{z} / \Delta v^{z}$ for the average country. However, the size of the China impact may vary among countries as a result of differences in their $\varepsilon_{z}^{*}$. For example, the impact would be greater for a country whose varieties of $M$ and $P$ were more closely substitutable for Chinese varieties. The impact should also be larger on a country's exports than on its total output, part of which is sold in the more protected home market. However, the output structures of smaller or more open countries, which sell less of their output in their home markets, should be more affected than those of countries that are larger or have higher trade barriers.

This exposition of our method has for simplicity referred to a single endowment ratio between two factors, $B$ and $N$, whereas our empirical analysis will also include a third factor, labour $(L)$, and hence two factor ratios, $B / L$ (the share of educated workers in the labour force) and $N / L$ (the land/labour ratio). Non-human capital is left out, on the grounds that it is internationally mobile and thus does not influence the comparative advantage of individual countries (Wood 1994: Section 2.2).

As in most other applications of HO theory, our method assumes that all countries have identical and homothetic preferences, but this obviously inaccurate assumption probably does not much affect our results. The main risk is that China's preferences might differ so greatly from those of other countries that the effects of its endowments on its trade, and hence on the sectoral structures of other developing countries, would differ greatly from the effects of their own endowments on their sectoral structures. This risk is reduced by China's per capita income being fairly close to the average per capita income of all developing countries (so that non-homotheticity should not have a big effect). Nor do our results suggest that there is a big difference between China and other countries in their relative domestic demands for $M$ and $P{ }^{6}$

\section{Data sources and problems}

Our data include all countries with populations above one million for which data are available. The complete dataset, with further information on sources and definitions, is available on request.

\footnotetext{
${ }^{5}$ Further analytical support for this assumption is available from the authors on request.

${ }^{6}$ The POLS regressions reported in Section 5 accurately predict China's $M / P$ production ratio, given its endowments. They substantially under-predict China's $M / P$ export ratio, but this seems more likely to be because China's labour-intensive manufactured exports are inflated by their unusually high imported intermediate input content (Koopman et al., 2008) than because China has an unusually low domestic consumer preference for labour-intensive manufactures.
} 
Primary products, $P$, are close to Standard International Trade Classification (SITC) categories 0-4, which include processed products that are classified as manufactures in the International Standard Industrial Classification (ISIC). ${ }^{7}$ Labour-intensive manufactures, $M$, are a subset of SITC categories 5-9, chosen on the basis of their relatively low skilled/unskilled labour ratios: leather, rubber and wood products (61$64)$; textiles, clothing and footwear $(65,83-85)$, non-metallic mineral products (66 less precious stones 667), iron and steel (67), metal products (69), sanitary equipment (81), ships, bicycles and trains (78 less 781-784 and 79 less 792), furniture (82) and miscellaneous items (89 and 9 less 941, 971).

We also add to $M$ electronics (SITC Rev. 2 divisions 75-77; ISIC Rev. 2 group 383), but only for developing countries, in some of which labour-intensive assembly of such products is a major export activity. Classifying electronics as labour-intensive or skillintensive simply on the basis of a country's developing or developed status is crude, but the best that can be done with the available data (and we test the sensitivity of our results to omitting electronics from $M$ ). This specific problem, moreover, illustrates a more general problem, which is the internal heterogeneity of our product categories: the composition of $M$ varies across countries with their endowments (Schott, 2003); and for each country it differs between exports and output (the former including more items with low trade costs).

Our export data are from UNCTAD. ${ }^{8}$ Our output data combine UN national accounts statistics with UNIDO industrial output statistics (whose coverage is unfortunately rather limited). Sectoral shares of ISIC manufacturing value added from UNIDO are used to split the value of manufacturing output in the UN national accounts between processed primary products (which are added to the UN agriculture and mining data to generate $P$ ), labour-intensive manufactures, and skill-intensive manufactures (a fuller explanation of these calculations is in Appendix A).

A weakness of both our output and our export data is that they are measured in terms of values rather than of volumes, without matching price or unit value series. This is a problem because the theory refers to volumes $\left(q_{M}\right.$ and $\left.q_{P}\right)$ and because the impact of China has involved changes in prices. In addition, the output and export data are not strictly comparable, because sectoral output is value added, while sectoral exports are measured gross of intermediate inputs (and re-exports). ${ }^{9}$ Imported intermediates grew rapidly during the period of China's entry into world markets, and are a large share of the value of some export products, including electronics (though the domestic content of non-assembly processing exports in China has risen (Aziz and Li, 2007: 8)).

Turning now to the factor endowment variables, land, $N$, is the surface area of the country concerned, and labour, $L$, is its adult (over-15) population. The number of workers with a basic education, $B$, is from Barro and Lee (2001): it includes those

\footnotetext{
${ }^{7} P$ also includes a few SITC 5-9 categories: non-ferrous metals (68), radioactive material (524), pearls and precious stones (667), zoo animals and pets (941) and non-monetary gold (971).

${ }^{8}$ Our data are similar to those in UNCTADstat (UNCTAD, 2010), but go back further (years prior to 1995 are not included in UNCTADstat) and are based on SITC Rev. 2 (whereas UNCTADstat is based on Rev. 3). We downloaded our data in 2006-7, prior to the creation of UNCTADstat (which uses better methods of estimating missing data).

${ }^{9}$ Input-output tables can be used to separate off the value added content of exports, but do not exist for enough countries, years and sectors (the best available data are those of Nicita and Olarreaga, 2007).
} 
with complete primary schooling and with secondary (but not tertiary) schooling. Narrower (omitting complete secondary) and broader (including incomplete primary) measures of $B$ yielded worse statistical results.

These skill and land variables fail to capture variation in the quality of endowments, especially over time. Length of schooling is an acceptable cross-country proxy for human capital, because it is correlated with variation in the quality of schooling and non-school learning, but it is less reliable as a measure of changes over time, for example because rises in school attendance may be associated with falls in school quality. The surface area measure of $N$ not only fails to reflect differences among countries in what is on or under their land, but also stays the same over time for each country, regardless of (say) oil discoveries or desertification. However, this simple measure of natural resources has more explanatory power than alternative measures based on the limited data available on specific natural resources such as arable land and minerals (Wood and Mayer, 2001).

\section{Effect of China on world endowments}

The task of this section is to estimate the impact of China's opening on world factor endowments. It requires a method of aggregating endowments across countries. In principle, the right method would be to weight each country's endowments by the effect (per unit of the factors) that they have on world prices of $M$ and $P$. This effect should depend on how productively the country uses its factors, what proportion of them is used to produce $M$ and $P$, and how much the country is involved in trade. In practice, we lack the data to apply this method, but its logic is helpful in suggesting simpler approximations and in understanding their limitations.

The method implicit in a well-known paper by Freeman (2006) is to classify countries as open or closed, and then simply to add up the endowments of the open ones. Thus, for example, labelling for brevity the $B / L$ ratio as $b$, its world average would be

$b_{t}^{*}=\sum_{z=1}^{=Z Z} B_{t}^{z} / \sum_{z=1}^{=Z Z} L_{t}^{z}=\sum_{z=1}^{=Z Z} s_{t}^{z} b_{t}^{z}$

where $t$ is the year, and $z$ indexes the $Z$ open countries. The factor ratios of individual countries, $b_{t}^{z}$, are weighted by their shares, $s_{t}^{z}$, of the open world's total labour force.

The impact of China is the difference between $b_{t}^{*}$ with and without China included in $Z$ (and similarly for world average $N / L$, labelled for brevity below as $n$ ).

A concern about equation (6) is its polarised categorisation of countries as either fully integrated into the world economy or wholly detached from it, since all of them trade to some extent. We will thus use two alternative methods in our calculations. One is based on (6), but with $Z$ extended to include all countries for which endowment data exist, regardless of how much they trade. Our other method, following Spilimbergo et al. (1999) and Jaumotte and Tytell (2007), is to adjust the weight of each country by the extent of its involvement in trade. World average $b$ thus becomes 
$b_{t}^{o^{*}}=\sum_{z=1}^{=7} o_{t}^{z} B_{t}^{z} / \sum_{z=1}^{=2} o_{t}^{z} L_{t}^{z}=\sum_{z=1}^{=2} b_{t}^{z} \sum_{t}^{o_{t}^{z} L_{t}^{z}} o_{t}^{z} L_{t}^{z}=\sum_{z=1}^{=1} s_{t}^{o z} b_{t}^{z}$

where $o_{t}^{z}$ is the ratio of trade to GDP in country $z$ at time $t$, and $Z$ covers all countries with data. The world average, $b_{t}^{o *}$, is weighted by country shares, $s_{t}^{o z}$, of the world's openness-adjusted labour force. It can be calculated with and without China in $Z$, and the impact of China is the difference between the changes in these two estimates of $b_{t}^{o^{*}}$ over the period during which China opened to trade.

Equation (7), too, is open to criticism. The right measure of trade for this purpose is its domestic value added content, reflecting factor inputs, but in practice, as already mentioned, exports are measured gross of intermediate inputs and include re-exports, which distorts the calculation by giving undue weight to countries with high gross-tovalue-added trade ratios. It can also be argued that what drives a country's impact on world prices is not just its exports and imports but its production and consumption of tradable goods, so that equation (7) gives too little weight to large countries with low trade-to-tradables ratios. Relatedly, neither equation (6) nor (7) allows for the use of factors to produce goods other than $M$ and $P$, especially non-tradable ones.

The methods in both equation (6) and equation (7) are vulnerable to another criticism, which is that they fail to take account of differences among countries in efficiency or factor productivity. A country which produces more output per unit of factor input will tend to exert more influence on world prices, so its endowments should be given more weight in calculating the effective world average. The important question is how China's efficiency compares with that of other countries: in particular, if China is of below-world-average efficiency, equations (6) and (7) will overstate the impact of its opening on effective world endowments.

There is currently no accurate and accepted answer to this question, partly because of controversy about the undervaluation of China's exchange rate and about the size of its GDP at purchasing power parity (estimates of which were reduced substantially in 2007 by the International Comparisons Project). ${ }^{10}$ Casual observation suggests that China's efficiency is well below that of most developed countries, but well above that of most developing countries, especially in labour-intensive manufacturing, and hence probably not far from the relevant world average (implying that this potential error in applying equations (6) and (7) may not be serious).

Table 1 shows our two alternative estimates of the impact of China on world average $b$ and $n$ (the four numbers in bold). The 'world' covers 96 countries which accounted for $86 \%$ of its adult population in 1990. The trade-to-GDP ratios used in applying equation (7) measure 'trade' as the mean of merchandise exports and merchandise imports, are at official exchange rates, and are from the UNCTAD database. As well as the endowment ratios $b$ and $n$, the table contains information on another widelyused measure of human capital - average adult years of schooling. China's own endowment ratios are shown at the bottom of the table.

\footnotetext{
${ }^{10}$ This controversy also affects the trade-to-GDP ratio for China used in our application of equation (7), the openness-adjusted world endowment calculations.
} 
Considering first the labour-force-weighted numbers in the upper panel, the top row shows that world average endowments (with China included) changed in the expected directions during 1980-2000: years of schooling rose by one-fifth; the share of basiceducated workers in the labour force rose by one-tenth; and land per worker fell by one-third (because of population growth). The second row shows world averages without China, and the third row the proportional $(\log )$ effect of including China.

Including China hardly alters world average years of schooling in 2000, but it raises the world average share of basic-educated workers in the labour force by $0.09 \mathrm{log}$ points (about 10\%), which is one of our estimates of the impact of China on world average $b$. World average land per worker is reduced by including China: in 2000, this makes a difference of $0.19 \log$ points (about 20\%), which is one of our estimates of the impact of China on world average $n$.

The labour-force-weighted-and-openness-adjusted numbers are in the lower panel of Table 1. In both years, the openness adjustment increases world average skill ratios: more educated countries tend to have higher trade-to-GDP ratios, though to a lesser extent in 2000 than in 1980 because developing countries had become more open. The rise in the openness-adjusted average share of basic-educated workers over the period is almost entirely due to China. Including China causes the average to rise by $0.06 \mathrm{log}$ points more than if China is excluded (when it hardly alters). ${ }^{11}$ This number is our second estimate of China's impact on world average $b$.

In 1980, the openness adjustment raises world average land per worker (including China) above its purely labour-force-weighted level, because land-abundant countries tended to have higher trade-to-GDP ratios than land-scarce countries. This difference had vanished by 2000, because of large increases in exports from land-scarce Asian countries, one of which was China. Including China causes the world average to fall over the period by $0.10 \mathrm{log}$ points more than if China is excluded, and this number is our second estimate of China's impact on world average $n .^{12}$

In summary, we have two alternative estimates of the impact of China's opening on world average $b(+0.06$ and $+0.09 \log$ points $)$ and two alternative estimates of its impact on world average $n(-0.10$ and $-0.19 \log$ points). Either way, the impact on $b$ is roughly half the size of the impact on $n$. For both $b$ and $n$, the purely labour-forceweighted number is, as expected, larger than that which also adjusts for openness, the gap being smaller for $b$ than for $n$. The purely labour-force-weighted estimates, which simply add China's endowments to the rest of the world's, can be interpreted as upper limits. Even these upper limits are not as large as might have been expected, given China's immense size, but neither are any of our estimates trivially small.

\footnotetext{
${ }^{11}$ The rise appears roughly twice as large in the 1980s as in the 1990s, partly because China's $b$ rose faster (from 0.46 in 1980 to 0.54 in 1990 , and then to 0.58 in 2000), and partly because its trade/GDP ratio rose faster (from 0.07 in 1980 to 0.15 in 1990, and then to 0.21 in 2000).

${ }^{12}$ All of this fall appears to have occurred in the $1980 \mathrm{~s}$, partly because China's $n$ fell faster (from 1.45 in 1980 to 1.12 in 1990, and then to 0.98 in 2000), as a result of slowing population growth, and partly because its trade/GDP ratio rose faster (see previous footnote for details).
} 


\section{Effects of endowments on structure}

The task of this section is to estimate the effects of factor endowments on sectoral structure. Its results are used in the next section to translate our estimates of China's impact on world endowments into estimates of China's impact on the ratio of labourintensive manufacturing to primary production in other economies. We proceed, as explained earlier, by estimating the first, bracketed term of the right-hand side of equation (1) as an approximation (though of opposite sign) to what we should ideally estimate, which is the left-hand side of equation (2).

We use a panel of data on individual countries, with observations in three years (1980, 1990 and 2000) spanning the period of China's opening. ${ }^{13}$ Our dependent variable is the ratio of labour-intensive manufacturing to primary production in each country and year. We measure this ratio in terms of both output and exports: the former includes sales in both home and foreign markets, the latter sales only in foreign markets. We estimate the output regression for as many countries as possible (53), and the export regression both for these 53 countries and for a larger set of 91 countries - the extra 38 being countries with data on exports and endowments but not on output. A list of the countries is in Appendix B. China is excluded from the regressions.

The basic specification of the regression is

$$
\ln \left[q_{M t}^{z} / q_{P t}^{z}\right)=\xi+\xi_{s}^{z} \ln b_{t}^{z}+\xi_{s} \ln n_{t}^{z}+u_{t}^{z}
$$

in which $u$ is the error term, $t$ indexes time periods and $z$ as before indexes countries. It relates proportional differences in sectoral structure to proportional differences in endowment ratios. It is similar in spirit to earlier approaches to estimating Rybczynski equations (surveyed in Baldwin, 2008), although its form, derived from the approach to HO theory outlined in Section 2, is somewhat different, and its interpretation, as noted in Section 3, is complicated by the need to use data on output value rather than volume in its dependent variable. The main aim is to estimate $\xi_{b}$ and $\xi_{n}$, which we do by three methods: pooled ordinary least squares (POLS), fixed effects (FE) and first differences (FD), though the usefulness of the latter two methods is limited by the fact that our panel contains data on only three years (at intervals of a decade).

Because our interest is in China's impact on other developing countries, we include an intercept dummy $D_{1}$ for developing countries (in all three years). Because we are also interested in changes over time, we include time period dummies, too, separately for developed countries $\left(A_{1}\right.$ and $\left.A_{2}\right)$ and for developing countries $\left(D_{2}\right.$ and $\left.D_{3}\right)$. Table 2 defines the dummy variables (to be discussed further in the next section) and provides summary statistics for the other variables. The full specification is thus

$$
\ln \left(q_{M t}^{z} / q_{P t}^{z}\right)=\xi+\xi \xi_{b} \ln b_{t}^{z}+\xi_{n} \ln n_{t}^{z}+\xi_{A 1} A_{1}+\xi_{A 2} A_{2}+\xi_{\xi 1} D_{1}+\xi_{2} D_{2}+\xi_{3} D_{3}+u_{t}^{z}
$$

The results are presented in Table 3, whose three panels contain the output regressions, the 53-country export regressions and the 91-country export regressions. Its columns correspond to the variables in equation (9). In each panel, the top three

\footnotetext{
${ }^{13}$ In each year, variables are measured (where possible) as three-year centred averages.
} 
rows show the POLS, FE and FD results. The fourth row is a variant on the FD regression with only the dummy variables included, to be discussed in the next section.

Consider first the three POLS regressions. In all of them, the coefficients on $b$ and $n$ are of the expected sign (positive for $\xi_{b}$ and negative for $\xi_{n}$, because of the directions of the differences in factor intensity between $M$ and $P$ ), statistically significant, and big enough to matter. ${ }^{14}$ The coefficients in the output regression are both (absolutely) smaller than in the matching 53-country export regression. The output regression also fits the data a bit better than the 53-country export regression.

There is not much difference in the values of $\xi_{b}$ and $\xi_{n}$ between the 53-country and 91country export regressions, nor in their goodness of fit. The extra 38 countries, almost all developing, have a much lower average ratio of labour-intensive manufactured to primary exports (unlogged, it is 0.16 , compared to 0.62 for the 53 countries). But this is explained largely by their lower endowments of skill $(b$, the share of basic-educated workers in the labour force, is on average $25 \%$ for the 38 extra countries, compared to $44 \%$ for the 53 countries) and by their higher land/labour ratios ( $n$ averaging about 4 $\mathrm{km}^{2}$ per 100 workers, compared to $2 \mathrm{~km}^{2}$ for the 53 countries). ${ }^{15}$ The numbers cited in this paragraph are derived from those in Table 2.

In all three POLS regressions, the coefficient on the developing-country dummy, $D_{1}$, is negative, significant and of similar size. Its value of -0.7 implies that the $M / P$ ratio for both output and exports is on average in developing countries roughly half of what would be predicted for developed countries with the same endowments of skill and land. The inclusion of the $D_{1}$ dummy also lowers the value of $\xi_{b} \cdot{ }^{16}$ A plausible interpretation is that developed countries are better endowed, relative to developing countries, with the skills needed for labour-intensive manufacturing than is implied by comparing their numbers of primary and secondary school graduates - as a result partly of better-quality schooling and partly of more training and practical experience.

In the FE and FD regressions, $D_{1}$ disappears. Moreover, in the FE and FD regressions, all the estimates of $\xi_{b}$ and $\xi_{n}$ are insignificantly different from zero at conventional test levels, and about half have the wrong sign (five out of six for $\xi_{n}$ ). ${ }^{17}$ The implication is that endowments have no effect on sectoral structure, which is hard to believe. There are also plausible econometric reasons for the insignificant FE and FD estimates of $\xi_{b}$ and $\xi_{n}$. These methods reduce the ratio of signal to noise, biasing coefficients towards zero and raising standard errors; and this problem is particularly serious with our data, partly because endowments change slowly over time, compared to their cross-section

\footnotetext{
${ }^{14}$ In these respects, they resemble the coefficients estimated in our earlier work (Mayer and Wood, 2001; Wood and Mayer, 2001), using a different measure of skill (average years of schooling).

${ }^{15}$ The coefficients $\xi_{b}$ and $\xi_{n}$ in the 91-country regression do differ slightly from those in the 53-country regression. The lower $\xi_{b}$ implies that the 38 countries have somewhat higher $M / P$ ratios than would be predicted from their skill ratios using the 53-country coefficients. The absolutely larger $\xi_{n}$ implies that the 38 countries have somewhat lower $M / P$ ratios than would be predicted from their land/labour ratios using the 53-country coefficients.

${ }^{16}$ By about 0.25 in the 53-country regressions and about 0.10 in the 91 -country regression.

${ }^{17}$ Although our model is, in theory, not dynamic (sectoral structure depends on current endowments), there may in practice be lags, so we also tried four methods of GMM estimation (details on request). This yielded a higher proportion of sensible signs, but still only a small proportion of coefficients that were statistically significant at conventional levels.
} 
variation, and partly because our measures of endowments are subject to even more error in time-series than in cross-section.

In estimating the impact of China, we thus use the POLS estimates of $\xi_{b}$ and $\xi_{n}$, both because they are likely to be more accurate than the FE and FD estimates and because they yield more convincing estimates of the China impact (which was surely greater than zero). However, we shall allow for the doubts aroused by these widely differing results by interpreting the POLS-based estimates of the impact as upper limits.

For reasons explained in Section 2, we re-ran the POLS regressions with electronics excluded from labour-intensive manufacturing in developing countries. Electronics is already excluded for developed countries, so this amendment enlarged the negative coefficients on $D_{1}$. It hardly changed $\xi_{n}$, but somewhat reduced $\xi_{b}$, particularly in the 53-country export regression, because electronics exports are of most importance for the well-educated developing countries of East Asia. ${ }^{18}$

\section{Predicted impact of China}

Table 4 contains our estimates of the impact of China's opening on the ratio of labourintensive manufacturing to primary production in other countries. These estimates are based on an expansion (with two factor ratios, and proportional changes expressed in $\log$ ) of equation (1)

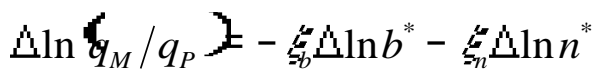

where $\Delta \ln b^{*}$ and $\Delta \ln n^{*}$ are our estimates of the impact of China on world average endowments of $B / L$ and $N / L$ from Table 1 , and $\xi_{b}$ and $\xi_{n}$ are our POLS estimates of the effects of endowment ratios on the $M / P$ ratio from Table 3 . The terms have negative signs because a change in the world average shifts the relative endowment ratios of individual countries in the opposite direction (for example, since China's opening reduced world average $n$, it made other countries relatively more landabundant).

We have two estimates of $\Delta \ln b^{*}$ and $\Delta \ln n^{*}$ (one labour-force-weighted and the other also openness-adjusted), and hence, in the two columns of Table 4, two alternative sets of estimates of the impact of China on $M / P$ ratios. We also calculate separately the impact on the $M / P$ output ratio (in the upper part of Table 4) and the $M / P$ export ratio (in its lower part). The lower part has two rows, based on our 53-country and 91country estimates of $\xi_{b}$ and $\xi_{n}$ for exports, though the results are almost the same (the differences in the coefficients happen to offset one another). We also show, in square brackets beneath each number, the range generated by raising or lowering the POLS estimates of $\xi_{b}$ and $\xi_{n}$ by one standard deviation.

The results suggest that China's opening to trade reduced the ratio of labour-intensive manufacturing to primary output in other countries by 0.05 to $0.14 \log$ points. The impact on the corresponding export ratio was a reduction of 0.07 to $0.21 \log$ points. The smaller estimated impact on output than on exports is in line with the theoretical

\footnotetext{
${ }^{18}$ Excluding (including) electronics, $\xi_{b}$ is $0.51(0.60)$ for output, $0.56(0.77)$ for 53-country exports, and 0.52 (0.60) for 91-country exports.
} 
expectation that China's opening would have less effect on sales in countries' home markets than in their export markets. The ranges reflect the differences between our alternative estimates of $\Delta \ln b^{*}$ and $\Delta \ln n^{*}$ and the imprecision of our POLS estimates of $\xi_{b}$ and $\xi_{n}$. We can be more confident that the numbers at the high ends of the ranges are upper limits on the China impact than that those at the other ends of the ranges are lower limits (mainly because the POLS estimates may be biased upward).

These numbers measure the impact of China's opening on the sectoral structure of an average country. The direction of the impact must have been the same for all other countries, since it arose from a shift in world average endowments. However, the size of the impact may have varied among countries, for two different sorts of reasons.

First, the induced change in the $M / P$ ratio may have varied for reasons mentioned in Section 2. The export and output structures of countries whose varieties of $M$ and $P$ were more substitutable for Chinese varieties would have been more strongly affected by China's opening. The output (but not the export) structures of countries that were smaller or had lower trade barriers would also have been more strongly affected.

Second, the economic significance of a given log change in the $M / P$ ratio depends on the initial level of this ratio, which in turn varies with a country's endowments. If the $M / P$ ratio is very high or very low - as in countries that are highly specialised in either labour-intensive manufactures or primary products - changes in the log of this ratio have tiny effects on the share of $M$ in $M+P .{ }^{19}$ The effect on the share is largest where the initial $M / P$ ratio is close to unity: the maximum possible change in the share is one quarter of the log change in the $M / P$ ratio.

Converting changes in ratios into changes in shares also puts the numbers in Table 4 into perspective, and in particular makes them seem smaller. Given the average $M / P$ ratios for output and exports for the countries in our data (Table 2), the China-induced changes in the log of this ratio need to be divided by between four and five to arrive at changes in the share of $M$ in $M+P$. For output, the estimated impact of China on this share for an average country was a reduction of between 1 and 3.5 percentage points, and for exports a reduction of between 1.5 and 5 percentage points. The true impacts are probably below the midpoints of these ranges, as explained earlier - reductions of about 2 percentage points for output and 3 percentage points for exports.

In assessing the practical significance of these numbers, it should also be borne in mind that $M+P$ is only part of a country's total output, and that $M$ is only the labourintensive part of narrowly-defined (SITC) manufacturing. A fall in the share of $M$ in $M+P$ could be consistent with stability or growth of the other components of broad (ISIC) manufacturing, namely the skill-intensive part of SITC manufacturing and the processing of primary products (which is included in our $P$ ). Moreover, both these other components should have been stimulated by China's opening, so that for at least some developing countries, our estimates of the fall in the share of $M$ must overstate the 'de-industrialising' effect on the broader ISIC definition of manufacturing.

\footnotetext{
${ }^{19}$ The derivative of the share with respect to the $\log$ ratio, $\ln r$, is $r /(1+r)^{2}$, with a maximum value of 0.25 when $r=1$. When $r=10$ or 0.1 , the derivative is only 0.08 .
} 


\section{Comparison with actual changes}

How do the predicted changes in $M / P$ ratios compare with actual changes? Did $M / P$ ratios in other countries fall, or did they rise less than would otherwise have been expected, after China's opening? Some answers to these questions can be obtained from the coefficients on the time dummy variables in the regressions in Table $3{ }^{20}$ It is assumed that the impact of China was concentrated in the 1990s (China's trade policy changed most in the second half of the 1980s, and the effects would have been felt in other countries with some lag). It is also assumed that other forces causing changes in $M / P$ ratios during the 1980s continued in the 1990s, so that the impact of China can be detected by comparing changes over the 1990s with changes over the 1980s. ${ }^{21}$

For developed countries, the relevant comparison in the POLS regressions is between $A_{1}$, which measures any step change in 1990 relative to 1980, and $A_{2}$, which measures any further step change by 2000 . In the FD regressions, from which $A_{1}$ vanishes, $A_{2}$ measures the difference between changes in the 1990s and in the 1980s. None of the results suggests that China had a negative impact: in all three POLS regressions, the coefficients on $A_{2}$ are larger than on $A_{1}$, and in the FD regressions, the coefficients on $A_{2}$ are positive (albeit insignificant), implying that $M / P$ output and export ratios rose more, not less, in the 1990s than in the 1980s. A possible explanation is that by 1990 most truly labour-intensive manufacturing in developed countries had ceased, and that the rise in $M / P$ in the 1990s reflects the expansion of other, skill-intensive activities within our coarse 'labour-intensive' aggregate.

In developing countries, the impact of China on which is the main focus of this paper, there is, by contrast, some evidence of a downward shift in $M / P$ ratios. In the POLS regressions, $D_{2}$, which measures any step change in 1990, has to be compared with $D_{3}$, which measures any further step change by 2000 , while in the FD regressions, the key variable is $D_{3}$, which shows the difference between changes in the 1990s and in the 1980s. In the output regressions in the top panel of Table 3, the POLS coefficient on $D_{3}$ is smaller than that on $D_{2}$, by -0.05 , which is also the size of the coefficient on $D_{3}$ in the FD regression (though this is far from significant). The conclusion is that the $M / P$ output ratio in developing countries in 2000 was about $0.05 \log$ points lower than would have been expected from its trend in the 1980s, which is consistent with our predicted 0.05-0.14 log points reduction as a result of China's opening.

Evidence of a China impact can be seen also in the export regressions in the middle panel of Table 3 (whose 53-country coverage matches that of the output regressions). In the POLS regression, the coefficients on $D_{2}$ and on $D_{3}$ are both positive, indicating upward shifts in the $M / P$ export ratios of developing countries in both the 1980 s and the 1990s. But the shift in the 1990s is smaller than in the 1980 s, by $0.20 \log$ points.

\footnotetext{
${ }^{20}$ We re-ran these regressions with individual-country endowment ratios normalised on without-China world average endowments in the year concerned, to see whether some of the actual changes could be explained by changes in the endowments or openness of countries other than China. This made almost no difference to the results, other than to shift all the intercepts.

${ }^{21}$ The period covered by these calculations could in principle be altered, for example by going further back than 1980 and (when more data become available) further forward than 2000. This would have some advantages (fuller capture of the post-1990 China impact) but also disadvantages (making it less plausible to argue that other causes of change in $M / P$ were the same before as after 1990).
} 
The coefficient on $D_{3}$ in the FD regression is similar, -0.22 (though insignificant). The $M / P$ export ratio of developing countries was thus about $0.2 \log$ points lower in 2000 than it would have been if its rise of the 1980s had continued at the same rate, which again fits with our predicted reduction of $0.07-0.21 \log$ points as a result of China's opening - and with the prediction of a larger impact on exports than on output

The coefficients on $D_{2}$ and $D_{3}$ in the 91-country export regressions in the bottom panel of Table 3, which include 38 countries, mainly developing, for which we lack data on the $M / P$ output ratio, differ substantially from those in the middle panel. The coefficients on $D_{2}$ and $D_{3}$ in the POLS regression are both close to zero, implying little change in the $M / P$ export ratio in either the 1980s or the 1990s. However, the difference between the decades is negative (-0.06 log points), as is the coefficient on $D_{3}$ in the FD regression, which suggests a rather larger change (-0.12 log points). The 91-country export results thus again fit reasonably well with our prediction of a 0.07 $0.21 \log$ points reduction in the 1990s as a result of China's opening.

In Table 5, to examine actual outcomes more closely, we divide developing countries into five regional groups (East Asia, South Asia, Latin America, Middle East and subSaharan Africa). For each group, and for China, the table shows the average changes in $M / P$ ratios in the 1980s and 1990s and the differences between these decades, for output and for the two sets of export data (53 and 91 countries). The table also shows the standard deviations within each group, which in almost all cases exceed the averages, partly because of genuine differences among countries and partly because of errors of measurement in the data, amplified by differencing and double-differencing.

To clarify the relationship between the averages in Table 5 and the regressions in Table 3, we show, in the fourth row of each panel of Table 3, a variant on the FD regression that excludes the (statistically insignificant) endowment variables and includes only the dummy variables. For developed countries, the differences between decades in Table $5(0.11,0.03$ and 0.03$)$ are the same as the coefficients on $A_{2}$ in the fourth-row regressions (and close to those in the third-row regressions). For developing countries as a group, these differences are the same as the coefficients on $D_{3}$ in the fourth-row regressions, which again are close to those in the third-row regressions. $^{22}$

The numbers for China in the 'difference' columns are positive: its output $M / P$ ratio was constant in the 1980s, but rose in the 1990s; while its export $M / P$ ratio rose much faster in the 1990s than in the 1980s. Two developing regions show a consistently opposite pattern of negative differences. One is East Asia, where rapid rises in both output and export $M / P$ ratios in the 1980s slowed sharply in the 1990s. Part of this slowdown may be a result of the Asian crisis of 1997. However, that China's opening contributed to this slowdown is plausible because of the similarity of trade patterns in other East Asian countries to those of China, and is supported by most other studies. ${ }^{23}$

\footnotetext{
${ }^{22}$ The 1980-90 averages for developed countries are the intercepts of the fourth-row regressions and for developing countries as a group are the intercepts plus the coefficients on $D_{2}$.

${ }^{23}$ See e.g. Ianchovichina and Walmsley (2003), Eichengreen et al. (2007) and Amann et al. (2009). However, Greenaway et al. (2008) conclude that China displaced manufactured exports from other Asian countries only to a very limited extent (mainly in developed-country markets).
} 
Omitting electronics from $M$ amplifies the slowdown, probably because competition from China was strongest in traditional labour-intensive manufactures. ${ }^{24}$

The other developing region where all the differences are negative is the Middle East and North Africa. Both output and export $M / P$ ratios rose in the 1980s, but for output the rise slowed in the 1990s and for exports it was sharply reversed. It seems unlikely that these changes were caused mainly by China's opening. This region's exports are dominated by oil, and the $M / P$ ratio (since it is measured in value rather than volume) is strongly affected by the oil price. China probably had only a small effect on the oil price up to 2000, although labour-intensive manufacturing in the non-oil countries of this region must have suffered from Chinese competition in the 1990s.

The difference between the two decades in the $M / P$ output change is negative also for Latin America, where the ratio rose in the 1980s but fell in the 1990s. This pattern is consistent with the widely-held view that labour-intensive manufacturing in the region contracted as a result of greater competition from imports from China and other Asian countries. ${ }^{25}$ However, this rise in imports was caused as much by Latin America's liberalisation of its own trade policies as by China's opening. Moreover, the region's $M / P$ export ratio moved in the other direction, from little change in the 1980s to rapid rise in the 1990s. One likely cause is regional integration schemes that opened North America to Latin American manufactured exports (e.g. NAFTA, which took effect in 1994, and the Caribbean Basin Recovery Expansion Act of 1990). Many countries in Latin America also introduced structural policies to improve the competitiveness of their manufactured exports (Melo, 2001).

The averages for South Asia are hard to interpret because of wide variation among its few countries. The rise in the $M / P$ output ratio in the 1990 s, after remaining constant in the 1980s, reflects the experience mainly of Bangladesh, whose $M / P$ export ratio also rose faster in the 1990s, protected from Chinese competition by WTO rules on textiles and clothing. There was little difference between the decades in the changes in the output or the export $M / P$ ratio in India, which remained largely closed to trade even after the 1991 reforms because of its size and poor infrastructure, and could not have been greatly affected by China's opening. The $M / P$ export ratio rose in most South Asian countries in both decades, but for the larger set of countries in the last column of Table 5 the rise slowed sharply in the 1990s: political events in Afghanistan, Nepal, Pakistan and Sri Lanka must have contributed to this deceleration, but part of it can plausibly be attributed to China's opening. ${ }^{26}$

The averages for Sub-Saharan Africa in Table 5 are also hard to interpret. For output, they suggest little change in the $M / P$ output ratio in the 1980 s or the 1990 s, contrary to concerns about the shrinkage of manufacturing as a result of the reduction of policy barriers to imports, ${ }^{27}$ including those from China, but are based on only 7 countries.

\footnotetext{
${ }^{24}$ Excluding (including) electronics, for East Asia the output change difference is $-0.29(-0.19)$, the 53country export change difference is $-0.82(-0.45)$, and the 91 -country export change difference is -0.62 (-0.34). For no other region does the exclusion of electronics much alter the results.

${ }^{25}$ Lall et al. (2005), Devlin et al. (2006), Freund and Ozden (2009), Lederman et al. (2008).

${ }^{26}$ Yusuf et al. (2006) and Dimaranan et al. (2009) emphasise that the effect of China on South Asia's manufactured exports varies among products, and conclude that the future evolution of these exports will depend heavily on the speed at which China upgrades its own exports.

${ }^{27}$ See e.g. Goldstein et al. (2006), Broadman (2007), Kaplinsky and Morris (2008).
} 
Nor can much weight be put on the export averages, although they show the expected negative differences between the 1980s and the 1990s both for these 7 countries and (slightly) for the larger group of 20 countries. This is because the $M / P$ export ratio is so low in most African countries that the estimated changes in Table 5, and especially the differences in changes, are probably dominated by measurement errors. However, for three important African producers of manufactures - Kenya, Mauritius and South Africa - the changes in both output and export ratios are negative, which is consistent with the expected impact of China, though the output ratio declines were a result also of reduction of their own policy barriers to imports.

\section{Conclusions}

This paper has attempted to measure the effects of China's opening to the world on the sectoral structures of other countries, especially developing ones and especially on the balance between labour-intensive manufacturing and primary production, which matters for overall economic progress, for income distribution and for employment. Its method has been to apply Heckscher-Ohlin trade theory, treating China's opening as a shift in effective world average factor endowments which altered the relative endowments and hence the comparative advantage of all other countries.

Subject to various qualifications discussed in the paper, we estimate that China's opening lowered the share of labour-intensive manufacturing in the sum of labourintensive manufacturing and primary output in other countries by between 1 and 3.5 percentage points, and the corresponding export share by between 1.5 and 5 points. We are more confident that the larger numbers in these ranges are upper limits than that the smaller ones are lower limits. These are average effects. China's opening to trade is likely to have had more effect on countries whose goods were similar to those made in China, and (for output) in smaller and more open countries. The impact of China on these shares was also larger in countries which produce substantial amounts of both labour-intensive manufactures and primary products than on countries which are highly specialised in one of these sectors.

We compare our estimates of China's impact on sectoral structure with actual changes in sectoral structure in developing countries in the 1980s and 1990s. On average for the 33 developing countries for which all the necessary data exist, the ratio of labourintensive manufacturing to primary production rose more slowly during the 1990s than during the 1980s, for both output and exports. The same was true of exports for a larger set of 65 developing countries. These changes are consistent in both direction and size with our estimates of the average impact of China's opening.

A closer examination, dividing these developing countries into regions, suggests that the impact of China was clearest on the rest of East Asia, whose countries are open to trade and produce goods similar to those made in China. In other regions, changes in actual ratios of labour-intensive manufacturing to primary production, whether falls or rises, appear to have been dominated by other, region-specific influences, or to have varied widely among individual countries, with China as just one determinant of the direction and size of the outcomes.

The frequent dominance of other influences is partly because the impact of China was fairly small. Despite China's vast size and amazing growth, our estimates suggest that 
its opening did not on average have a large effect on the broad sectoral structures of other countries, and we can see no plausible modification of our approach that could make this effect appear much larger. The impact is not trivial, and in some countries and more narrowly defined sectors must have been much bigger than average, but our estimates imply that the common view of China's emergence as a threat to economic progress and equity in the rest of the developing world is exaggerated.

China's opening to the world was a one-off event, which caused a step change in the comparative advantage of other countries. Its rapid growth, based on accumulation of more skills, capital and modern technology, is by contrast a continuing event, and one whose effects will change with the passage of time. Up to now, China's growth has mainly amplified the effects of its opening, raising both its supply of labour-intensive manufactures and its demand for primary products. Over the longer-term future, this rising demand for primary products will continue, but China's accumulation of skills will move it out of labour-intensive manufacturing, tending to increase rather than (as initially) to reduce the size of this sector in other developing countries. ${ }^{28}$

\footnotetext{
${ }^{28}$ The evidence in Dimaranan et al. (2009) supports this claim.
} 


\section{References}

Amann, E., B. Lau and F. Nixson (2009). Did China hurt the textiles and clothing exports of other Asian economies, 1990-2005? Oxford Development Studies. 37(4): 333-362.

Amiti, M., and C. Freund (2008). The anatomy of China's export growth. Policy Research Working Paper 4628. World Bank. Washington DC.

Aziz, J., and X. Li (2007). China's changing trade elasticities. Working Paper 07/266. International Monetary Fund. Washington DC.

Baldwin, R. (2008). The Development and Testing of Heckscher-Ohlin Trade Models: A Review. Cambridge MA: MIT Press.

Barro, R., and J.-W. Lee (2001). International data on educational attainment: updates and implications. Oxford Economic Papers. 53(3): 541-563.

Broadman, H. (2007). Africa's Silk Road: China and India's New Economic Frontier. Washington DC: World Bank.

Davis, D., and D. Weinstein (2001). An account of global factor trade. American Economic Review. 91(5): 1423-53.

Devlin, R., A. Estevadeordal and A. Rodriguez-Clare (eds) (2006). The Emergence of China. Opportunities and Challenges for Latin America and the Caribbean.

Washington, DC: Inter-American Development Bank.

Dimaranan, B., E. Ianchovichina and W. Martin (2006). Competing with giants: who wins, who loses? In L. Winters and S. Yusuf (eds), Dancing with Giants. China, India, and the Global Economy. Washington DC: World Bank.

Dimaranan, B., E. Ianchovichina and W. Martin (2009). How will growth in China and India affect the world economy? Review of World

Economics/Weltwirtschaftliches Archiv. 145(3): 551-571.

Dooley, M., D. Folkerts-Landau and P. Garber (2004). The revived Bretton Woods system: the effects of periphery intervention and reserve management on interest rates and exchange rates in center countries. NBER Working Paper 10332. National Bureau of Economic Research, Cambridge MA.

Eichengreen, B., Y. Rhee and H. Tong (2007). China and the exports of other Asian countries. Review of World Economics/Weltwirtschaftliches Archiv. 143(2): 201-226.

Freeman, R. (2006). Labor market imbalances: shortages, or surpluses, or fish stories? Paper presented at Boston Federal Reserve Conference. Available at http://www.bos.frb.org/economic/conf/conf51/papers/freeman.pdf

Freund, C., and C. Ozden (2009). The effect of China's exports on Latin American trade with the world. In D. Lederman, M. Olarreaga and G. Perry (eds), China's and 
India's Challenge to Latin America. Opportunity or Threat? Washington DC: The World Bank.

Fu, X., R. Kaplinsky and J. Zhang (2010). The impact of China's exports on global manufactures prices. SLPTMD Working Paper 32, Department of International Development, Oxford University.

Gallagher, K., J. Moreno-Brid and R. Porzecanski (2008). The dynamism of Mexican exports: lost in (Chinese) translation? World Development. 36(8): 1365-1380.

Goldstein, A., N. Pinaud, H. Reisen and X. Chen (2006). The Rise of China and India: What's in it for Africa? Paris: OECD Development Centre.

Greenaway, D., A. Mahabir and C. Milner (2008). Has China displaced other Asian countries' exports? China Economic Review. 19(2): 152-169.

Hanson, G., and R. Robertson (2010). China and the manufacturing exports of other developing countries. In R. Feenstra and S. Wei (eds), China's Growing Role in World Trade. Chicago: University of Chicago Press.

Hummels, D., and A. Skiba (2004). Shipping the good apples out? An empirical confirmation of the Alchian-Allen conjecture. Journal of Political Economy. 112(6): 1384-1402.

Ianchovichina, E., and T. Walmsley (2003). The impact of China's WTO accession on East Asia. Policy Research Working Paper 3109. World Bank. Washington DC.

Jaumotte, F., and I. Tytell (2007). The globalisation of labor. World Economic Outlook, April, Chapter 5:161-192.

Kaplinsky, R., and M. Morris (2008). Do the Asian drivers undermine export-oriented industrialization in SSA? World Development. 36(2): 254-273.

Koopman, R., Z. Wang and S.-J. Wei (2008). How much of Chinese exports is really made in China? Assessing domestic value-added when processing trade is pervasive. NBER Working Paper 14109. National Bureau of Economic Research, Cambridge MA.

Lall, S., J. Weiss and H. Oikawa (2005). China's competitive threat to Latin America: an analysis for 1990-2002. Oxford Development Studies. 33(2): 163-194.

Lederman, D., M. Olarreaga and E. Rubiano (2008). Trade specialization in Latin America: the impact of China and India. Review of World Economics/Weltwirtschaftliches Archiv. 144(2): 248-271.

Mayer, J., and P. Fajarnes (2008). Tripling Africa's primary exports: What? How? Where? Journal of Development Studies. 44(1): 80-102.

Mayer, J., and A. Wood (2001). South Asia's export structure in a comparative perspective. Oxford Development Studies. 29(1): 5-29. 
Melo, A. (2001). Industrial policy in Latin America and the Caribbean at the turn of the century. Working Paper 459. Inter-American Development Bank. Washington DC.

Mesquita Moreira, M. (2007). Fear of China: is there a future for manufacturing in Latin America? World Development. 35(3): 355-376.

Nicita, A., and M. Olarreaga (2007). Trade, production and protection database, 1976-2004. World Bank Economic Review. 21(1): 165-71.

Rodrik, D. (2006). What's so special about China's exports? China and World Economy. 14(5): 1-19.

Romalis, J. (2004). Factor proportions and the structure of commodity trade. American Economic Review. 94(1): 67-90.

Schott, P. (2003). One size fits all? Heckscher-Ohlin specialisation in global production. American Economic Review. 93(3): 686-708.

Schott, P. (2008). The relative sophistication of Chinese exports. Economic Policy. January: 5-49.

Spilimbergo, A., J. Londono and M. Szekely (1999). Income distribution, factor endowments, and trade openness. Journal of Development Economics. 59(1): 77-101.

UNCTAD (2010). UNCTADstat online database. Available at http://unctadstat.unctad.org/TableViewer/tableView.aspx?ReportId=110

Winters, L., and S. Yusuf (eds) (2006). Dancing with Giants. China, India, and the Global Economy. Washington DC: World Bank and Institute of Policy Studies.

Wood, A. (1994). North-South Trade, Employment and Inequality. Oxford: Clarendon Press.

Wood, A. (2009). A practical Heckscher-Ohlin model. Working Paper 170. Department of International Development, Oxford University.

Wood, A., and J. Mayer (2001). Africa's export structure in a comparative perspective. Cambridge Journal of Economics. 25(3): 369-94.

Xu, B. (2007). Measuring China's export sophistication. Mimeo. Available at http://www.ceibs.edu/faculty/xubin/Measuring.pdf

Yang, Y. (2003). China's integration into the world economy: implications for developing countries. Working Paper 03/245. International Monetary Fund. Washington DC.

Yusuf, S., K. Nabeshima and D. Perkins (2006). China and India reshape global industrial geography. In L. Winters and S. Yusuf (eds), Dancing with Giants. China, 
India, and the Global Economy. Washington DC: World Bank and Institute of Policy Studies. 


\section{Appendix A. Derivation of the output data}

Our output data were derived by combining UN national accounts statistics with the UNIDO Industrial Statistics Database 2006. Two problems had to be solved. The first was the difference between the Standard International Trade Classification (SITC), used in our trade data, and the International Standard Industrial Classification (ISIC) used in the UN and UNIDO output data. The second was that UN national accounts data in principle cover the whole of the economy, but at a high level of aggregation, whereas the more disaggregated UNIDO data refer only to broad manufacturing (and exclude the output of small firms).

Our primary category, $P$, is close to categories 0-4 of the SITC, including processed primary products $(P P)$, which the ISIC treats as manufactures. Correspondingly, we use the narrower SITC definition of manufactures (roughly categories 5-9), divided into labour-intensive manufactures $(N M L)$, skill-intensive manufactures $(N M H)$ and electronics $(E L)$, using the SITC categories specified in Section 3 of the main text. In algebra, the relationships are:

$P($ broad or SITC primary $)=N P($ narrow or ISIC primary $)+P P($ processed primary $) ;$ $N M$ (narrow or SITC manufacturing) $=B M$ (broad or ISIC manufacturing $)-P P$; $B M=P P+N M=P P+N M L+N M H+E L$.

For each country and year in which they were available, the UNIDO data on broad manufacturing value added were allocated among our categories as follows, where the numbers refer to ISIC (Rev. 2) 3-digit groups:

$P P: 311,313,314,353,354,372$

NML: 321, 322, 323, 324, 331, 332, 341, 342, 355, 356, 361, 362, 369, 371, 381, 390 $N M H: 351,352,382,384,385$

EL: 383

The resulting numbers were used to calculate four shares: $\psi_{P P B M}=P P / B M ; \psi_{N M L B M}=$ $N M L / B M ; \psi_{N M H B M}=N M H / B M ;$ and $\psi_{E L B M}=E L / B M$. These shares were then used to convert National Accounts sectoral output data for agriculture (NPA), mining (NPM) and ISIC manufacturing $\left(B M_{N A}\right)$ into $P$ and $N M$, as follows,

$P=N P A+N P M+\left(\psi_{P P B M} * B M_{N A}\right)$

$N M_{N A}=\left(1-\psi_{P P B M}\right) * B M_{N A}$

and to split up narrow manufacturing, as follows

$N M L_{N A}=\psi_{N M L B M} * B M_{N A}$

$N M H_{N A}=\psi_{N M H B M} * B M_{N A}$;

$E L_{N A}=\psi_{E L B M} * B M_{N A}$.

As explained in Section 3 of the main text, our category $M$ is defined for developing countries as $N M L_{N A}+E L_{N A}$, and for developed countries as $N M L_{N A}$. All the data used, and further details of the estimation process, are available on request. 


\section{Appendix B. Country coverage of the data}

The 53-country data set contains:

Developed countries (20 countries): Australia, Austria, Belgium and Luxembourg, Canada, Finland, France, Germany, Greece, Hungary, Ireland, Israel, Italy, Japan, Norway, Poland, Portugal, Spain, Sweden, United Kingdom, United States.

East Asia (6 countries): Hong Kong (China SAR), Indonesia, Malaysia, Philippines, Republic of Korea, Singapore.

South Asia (3 countries): Bangladesh, India, Sri Lanka.

Latin America (10 countries): Bolivia, Chile, Colombia, Costa Rica, Ecuador, El Salvador, Mexico, Trinidad and Tobago, Uruguay, Venezuela.

Middle East and North Africa (7 countries): Egypt, Iran, Jordan, Kuwait, Syrian Arab Republic, Tunisia, Turkey.

Sub-Saharan Africa (7 countries): Cameroon, Kenya, Malawi, Mauritius, Senegal, South Africa, United Republic of Tanzania.

The 91-country data set contains the following additional 38 countries:

Developed countries (6 countries): Bulgaria, Denmark, Netherlands, New Zealand, Romania, Switzerland.

East Asia (3 countries): Papua New Guinea, Taiwan (Province of China), Thailand.

South Asia (3 countries): Afghanistan, Nepal, Pakistan.

Latin America (11 countries): Argentina, Brazil, Cuba, Dominican Republic, Guatemala, Honduras, Jamaica, Nicaragua, Panama, Paraguay, Peru.

Middle East and North Africa (2 countries): Algeria, Iraq.

Sub-Saharan Africa (13 countries): Benin, Central African Republic, Democratic Republic of the Congo, Ghana, Guinea-Bissau, Mali, Mozambique, Niger, Rwanda, Sudan, Uganda, Zambia, Zimbabwe. 
Table 1

World average endowment ratios

(numbers in bold are estimates of the impact of China's opening to trade)

\begin{tabular}{|c|c|c|c|c|c|c|c|c|c|}
\hline & \multicolumn{3}{|c|}{ Adult years of schooling } & \multicolumn{3}{|c|}{$\begin{array}{l}\text { Basic-educated share } \\
\text { of labour force }(b=B / L)\end{array}$} & \multicolumn{3}{|c|}{$\begin{array}{c}\text { Land }\left(\mathrm{km}^{2}\right) \text { per } \\
100 \text { workers }(n=N / L)\end{array}$} \\
\hline & 1980 & 2000 & $\begin{array}{r}\log _{\mathrm{e}} \\
\text { change }\end{array}$ & 1980 & 2000 & $\begin{array}{r}\log _{\mathrm{e}} \\
\text { change }\end{array}$ & 1980 & 2000 & $\begin{array}{r}\log _{\mathrm{e}} \\
\text { change }\end{array}$ \\
\hline \multicolumn{10}{|l|}{ Labour-force-weighted average } \\
\hline Including China & 5.31 & 6.49 & 0.20 & 0.42 & 0.47 & 0.10 & 3.59 & 2.40 & -0.40 \\
\hline Excluding China & 5.48 & 6.52 & 0.17 & 0.41 & 0.43 & 0.05 & 4.33 & 2.89 & -0.41 \\
\hline Log difference & -0.03 & 0.00 & 0.03 & 0.03 & 0.09 & 0.06 & -0.19 & -0.19 & 0.00 \\
\hline \multicolumn{10}{|c|}{ Labour-force-weighted and openness-adjusted average } \\
\hline Including China & 5.68 & 6.64 & 0.16 & 0.46 & 0.50 & 0.08 & 4.23 & 2.43 & -0.55 \\
\hline Excluding China & 5.81 & 6.73 & 0.15 & 0.46 & 0.46 & 0.02 & 4.64 & 2.96 & -0.45 \\
\hline Log difference & -0.02 & -0.01 & 0.01 & 0.00 & 0.06 & 0.06 & -0.09 & -0.20 & -0.10 \\
\hline \multicolumn{10}{|l|}{ Memo item: } \\
\hline China's endowment ratios & 4.80 & 6.40 & 0.29 & 0.46 & 0.58 & 0.24 & 1.45 & 0.98 & -0.39 \\
\hline
\end{tabular}

Note: Data sources and calculations explained in text. The data cover 95 countries (plus China), including four countries omitted from the 91 country export regressions in later tables because their export data are not credible (Haiti, Myanmar, Sierra Leone and Togo). 
Table 2

Details of variables used in regressions

Mean Standard Maximum Minimum deviation

Dependent variable $\left(\log _{\mathrm{e}} M / P\right)$

$\begin{array}{lllll}\text { Output }(53 \text { countries }) & -0.83 & 1.04 & 2.24 & -3.48 \\ \text { Exports }(53 \text { countries }) & -0.48 & 1.52 & 2.54 & -4.18 \\ \text { Exports }(91 \text { countries }) & -1.05 & 1.84 & 2.78 & -7.31\end{array}$

Endowment ratios (logged)

\begin{tabular}{|c|c|c|c|c|}
\hline$b=B / L(53$ countries $)$ & -0.83 & 0.47 & -0.14 & -2.26 \\
\hline$b=B / L(91$ countries $)$ & -1.06 & 0.70 & -0.14 & -4.34 \\
\hline$n=N / L(53$ countries $)$ & -3.98 & 1.51 & -0.35 & -8.57 \\
\hline$n=N / L(91$ countries $)$ & -3.66 & 1.49 & -0.35 & -8.57 \\
\hline
\end{tabular}

Dummy variables

$A_{1} 1$ for developed countries in 1990 and 2000, 0 otherwise

$A_{2} 1$ for developed countries in 2000, 0 otherwise

$\mathrm{D}_{1} 1$ for developing countries in all three years, 0 otherwise

$\mathrm{D}_{2} 1$ for developing countries in 1990 and 2000, 0 otherwise

$D_{3} 1$ for developing countries in 2000,0 otherwise

Note: Summary statistics calculated from pooled data for 1980, 1990 and 2000. For the definition of the dummy variables, Eastern European countries are included in the developed-country group. On this basis, of the 53 countries, $38 \%$ are developed, and of the 91 countries, $29 \%$ are developed. China is omitted from all the regressions 
Table 3

Regression results 1980-2000

Dependent variable in all rows: $\log _{\mathrm{e}} q_{M} / q_{P}$

\begin{tabular}{|c|c|c|c|c|c|c|c|c|c|}
\hline \multirow[t]{2}{*}{ Method } & \multirow[t]{2}{*}{ Intercept } & \multicolumn{7}{|c|}{ Coefficients on independent variables } & \multirow[t]{2}{*}{$\mathrm{R}^{2}$} \\
\hline & & $\log _{\mathrm{e}} b$ & $\log _{\mathrm{e}} n$ & $A_{1}$ & $A_{2}$ & $D_{1}$ & $D_{2}$ & $D_{3}$ & \\
\hline \multicolumn{10}{|c|}{ Output ratio ( 53 countries, 3 years) } \\
\hline POLS & $\begin{array}{l}-1.06 \\
(0.00)\end{array}$ & $\begin{array}{c}0.60 \\
(0.01)\end{array}$ & $\begin{array}{l}-0.30 \\
(0.00)\end{array}$ & $\begin{array}{c}0.00 \\
(0.97)\end{array}$ & $\begin{array}{c}0.14 \\
(0.02)\end{array}$ & $\begin{array}{l}-0.75 \\
(0.01)\end{array}$ & $\begin{array}{c}0.00 \\
(0.97)\end{array}$ & $\begin{array}{l}-0.05 \\
(0.59)\end{array}$ & 0.57 \\
\hline $\mathrm{FE}$ & $\begin{array}{c}0.58 \\
(0.70)\end{array}$ & $\begin{array}{c}0.32 \\
(0.19)\end{array}$ & $\begin{array}{c}0.32 \\
(0.41)\end{array}$ & & $\begin{array}{c}0.21 \\
(0.04)\end{array}$ & & $\begin{array}{c}0.20 \\
(0.13)\end{array}$ & $\begin{array}{c}0.14 \\
(0.28)\end{array}$ & 0.12 \\
\hline FD & $\begin{array}{c}0.01 \\
(0.90)\end{array}$ & $\begin{array}{c}0.05 \\
(0.83)\end{array}$ & $\begin{array}{l}-0.14 \\
(0.80)\end{array}$ & & $\begin{array}{c}0.11 \\
(0.15)\end{array}$ & & $\begin{array}{c}0.09 \\
(0.56)\end{array}$ & $\begin{array}{l}-0.05 \\
(0.63)\end{array}$ & 0.02 \\
\hline FD & $\begin{array}{c}0.02 \\
(0.62)\end{array}$ & & & & $\begin{array}{c}0.11 \\
(0.15)\end{array}$ & & $\begin{array}{c}0.12 \\
(0.17)\end{array}$ & $\begin{array}{l}-0.06 \\
(0.61)\end{array}$ & 0.01 \\
\hline \multicolumn{10}{|c|}{ Export ratio (53 countries, 3 years) } \\
\hline POLS & $\begin{array}{l}-1.60 \\
(0.00)\end{array}$ & $\begin{array}{c}0.77 \\
(0.07)\end{array}$ & $\begin{array}{l}-0.50 \\
(0.00)\end{array}$ & $\begin{array}{c}0.14 \\
(0.13)\end{array}$ & $\begin{array}{c}0.20 \\
(0.05)\end{array}$ & $\begin{array}{l}-0.72 \\
(0.13)\end{array}$ & $\begin{array}{c}0.30 \\
(0.14)\end{array}$ & $\begin{array}{c}0.10 \\
(0.62)\end{array}$ & 0.48 \\
\hline $\mathrm{FE}$ & $\begin{array}{c}2.98 \\
(0.42)\end{array}$ & $\begin{array}{l}-0.28 \\
(0.63)\end{array}$ & $\begin{array}{c}1.06 \\
(0.27)\end{array}$ & & $\begin{array}{c}0.40 \\
(0.10)\end{array}$ & & $\begin{array}{c}0.83 \\
(0.01)\end{array}$ & $\begin{array}{c}0.60 \\
(0.05)\end{array}$ & 0.33 \\
\hline FD & $\begin{array}{c}0.24 \\
(0.05)\end{array}$ & $\begin{array}{c}0.21 \\
(0.74)\end{array}$ & $\begin{array}{c}0.82 \\
(0.52)\end{array}$ & & $\begin{array}{c}0.04 \\
(0.78)\end{array}$ & & $\begin{array}{c}0.48 \\
(0.18)\end{array}$ & $\begin{array}{c}-0.22 \\
(0.42)\end{array}$ & 0.03 \\
\hline FD & $\begin{array}{c}0.17 \\
(0.03)\end{array}$ & & & & $\begin{array}{c}0.03 \\
(0.83)\end{array}$ & & $\begin{array}{c}0.34 \\
(0.09)\end{array}$ & $\begin{array}{c}-0.21 \\
(0.46)\end{array}$ & 0.02 \\
\hline \multicolumn{10}{|c|}{ Export ratio (91 countries, 3 years) } \\
\hline POLS & $\begin{array}{l}-2.07 \\
(0.00)\end{array}$ & $\begin{array}{c}0.60 \\
(0.03)\end{array}$ & $\begin{array}{l}-0.56 \\
(0.00)\end{array}$ & $\begin{array}{c}0.14 \\
(0.06)\end{array}$ & $\begin{array}{c}0.21 \\
(0.02)\end{array}$ & $\begin{array}{c}-0.66 \\
(0.06)\end{array}$ & $\begin{array}{c}0.04 \\
(0.81)\end{array}$ & $\begin{array}{c}-0.02 \\
(0.86)\end{array}$ & 0.46 \\
\hline $\mathrm{FE}$ & $\begin{array}{c}1.99 \\
(0.46)\end{array}$ & $\begin{array}{l}-0.20 \\
(0.53)\end{array}$ & $\begin{array}{c}1.01 \\
(0.18)\end{array}$ & & $\begin{array}{c}0.42 \\
(0.04)\end{array}$ & & $\begin{array}{c}0.62 \\
(0.01)\end{array}$ & $\begin{array}{c}0.47 \\
(0.05)\end{array}$ & 0.36 \\
\hline FD & $\begin{array}{c}0.30 \\
(0.00)\end{array}$ & $\begin{array}{c}0.09 \\
(0.79)\end{array}$ & $\begin{array}{c}1.28 \\
(0.15)\end{array}$ & & $\begin{array}{c}0.02 \\
(0.85)\end{array}$ & & $\begin{array}{c}0.34 \\
(0.13)\end{array}$ & $\begin{array}{c}-0.12 \\
(0.51)\end{array}$ & 0.02 \\
\hline FD & $\begin{array}{c}0.19 \\
(0.01)\end{array}$ & & & & $\begin{array}{c}0.03 \\
(0.79)\end{array}$ & & $\begin{array}{c}0.12 \\
(0.40)\end{array}$ & $\begin{array}{l}-0.12 \\
(0.53)\end{array}$ & 0.00 \\
\hline
\end{tabular}

Note: All regressions exclude China. All the standard errors are clustered across countries, and the standard errors in the POLS regressions are robust. P-values are shown in parentheses. 
Table 4

Predicted impact of China's opening on ratio of labour-intensive manufacturing to primary production in other countries

Impact on $\log _{\mathrm{e}} M / P$ output ratio

Alternative estimates of impact on world endowment ratios

\begin{tabular}{cc}
\hline $\begin{array}{c}\text { Labour-force- } \\
\text { weighted }\end{array}$ & $\begin{array}{c}\text { Labour-force- } \\
\text { weighted and } \\
\text { openness-adjusted }\end{array}$ \\
\cline { 2 - 2 }-0.11 & -0.07 \\
{$[-0.14 ;-0.07]$} & {$[-0.09 ;-0.05]$}
\end{tabular}

Impact on $\log _{\mathrm{e}} M / P$ export ratio

53-country coefficients

$-0.16$

$-0.10$

$[-0.21 ;-0.11]$

$[-0.14 ;-0.07]$

91-country coefficients

$-0.16$

$-0.10$

$[-0.20 ;-0.12]$

$[-0.12 ;-0.07]$

Note: Calculations explained in text, using data from tables 1 and 3. The numbers in brackets indicate the effect of varying the regression coefficients on $b$ and $n$ by one standard deviation in each direction. 
Table 5

Changes in logged ratios of labour-intensive-manufacturing to primary output and exports, 1980-2000, regional averages

\begin{tabular}{|c|c|c|c|c|c|c|c|c|c|c|}
\hline \multirow{2}{*}{$\begin{array}{l}\text { Region (number } \\
\text { of countries in 53- } \\
\text { country data) }\end{array}$} & \multicolumn{3}{|c|}{ Output (53 countries) } & \multicolumn{3}{|c|}{ Exports (53 countries) } & \multicolumn{4}{|c|}{ Exports (91 countries) } \\
\hline & $\begin{array}{r}1980- \\
1990\end{array}$ & $\begin{array}{r}1990- \\
2000\end{array}$ & $\begin{array}{r}\text { Differ- } \\
\text { ence }\end{array}$ & $\begin{array}{r}1980- \\
1990\end{array}$ & $\begin{array}{r}1990- \\
2000\end{array}$ & $\begin{array}{r}\text { Differ- } \\
\text { ence }\end{array}$ & $\begin{array}{r}\text { Additional } \\
\text { countries }\end{array}$ & $\begin{array}{r}1980- \\
1990\end{array}$ & $\begin{array}{r}1990- \\
2000\end{array}$ & $\begin{array}{r}\text { Differ- } \\
\text { ence }\end{array}$ \\
\hline China & -0.02 & 0.24 & 0.26 & 0.34 & 1.13 & 0.79 & & 0.34 & 1.13 & 0.79 \\
\hline Developed (20) & 0.02 & 0.13 & 0.11 & 0.17 & 0.20 & 0.03 & 6 & 0.19 & 0.21 & 0.03 \\
\hline Developing (33) & 0.14 & 0.08 & -0.06 & 0.51 & 0.30 & -0.21 & 32 & 0.31 & 0.19 & -0.12 \\
\hline East Asia (6) & 0.43 & 0.24 & -0.19 & 1.20 & 0.75 & -0.45 & 3 & 0.88 & 0.54 & -0.34 \\
\hline Standard deviation & 0.48 & 0.37 & 0.28 & 1.07 & 0.76 & 1.03 & & 1.17 & 0.77 & 0.88 \\
\hline South Asia (3) & 0.00 & 0.29 & 0.29 & 0.77 & 0.81 & 0.04 & 3 & 0.79 & 0.38 & -0.41 \\
\hline Standard deviation & 0.15 & 0.23 & 0.25 & 0.79 & 0.49 & 0.71 & & 0.90 & 0.74 & 0.81 \\
\hline Latin America (10) & 0.10 & -0.07 & -0.17 & 0.04 & 0.73 & 0.69 & 11 & 0.04 & 0.46 & 0.43 \\
\hline Standard deviation & 0.38 & 0.57 & 0.64 & 1.01 & 0.76 & 1.23 & & 0.89 & 0.65 & 1.11 \\
\hline Middle East (7) & 0.21 & 0.07 & -0.14 & 0.57 & -0.43 & -1.00 & 2 & 0.46 & -0.73 & -1.19 \\
\hline Standard deviation & 0.42 & 0.51 & 0.86 & 1.24 & 1.79 & 2.42 & & 1.38 & 1.71 & 2.17 \\
\hline Sub-Saharan Africa (7) & -0.08 & 0.08 & 0.16 & 0.40 & -0.19 & -0.59 & 13 & 0.12 & 0.09 & -0.02 \\
\hline Standard deviation & 0.50 & 0.36 & 0.68 & 0.72 & 0.86 & 1.26 & & 0.81 & 1.08 & 1.66 \\
\hline
\end{tabular}

Notes: Regional averages are unweighted; Eastern Europe included in 'developed' group (Hungary and Poland in 53-country data; plus Bulgaria and Romania in 91-country data); East Asia excludes China; Latin America includes Caribbean; Middle East includes North Africa. 